Discussion Paper No. 07-060

International Cooperation on Innovation:

Empirical Evidence for German and Portuguese Firms

Pedro Faria and Tobias Schmidt

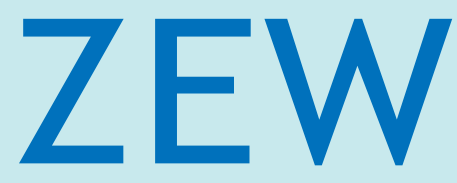

Zentrum für Europäische Wirtschaftsforschung $\mathrm{GmbH}$

Centre for European

Economic Research 
Discussion Paper No. 07-060

\section{International Cooperation on Innovation: Empirical Evidence for German and Portuguese Firms}

Pedro Faria and Tobias Schmidt

Download this ZEW Discussion Paper from our ftp server:

ftp://ftp.zew.de/pub/zew-docs/dp/dp07060.pdf

Die Discussion Papers dienen einer möglichst schnellen Verbreitung von neueren Forschungsarbeiten des ZEW. Die Beiträge liegen in alleiniger Verantwortung der Autoren und stellen nicht notwendigerweise die Meinung des ZEW dar.

Discussion Papers are intended to make results of ZEW research promptly available to other economists in order to encourage discussion and suggestions for revisions. The authors are solely responsible for the contents which do not necessarily represent the opinion of the ZEW. 


\section{Non-technical Summary}

Driven by more complex innovation projects and ever shorter innovation and product-life cycles, firms are faced with a demand for knowledge they cannot satisfy with their internal resources alone. Firms thus have to look for partners for their innovation projects, which has led to an increase of the number of innovation cooperations. The globalisation of firms' activities has contributed to the pressure to become more innovative and to conduct $\mathrm{R} \& \mathrm{D}$ and innovation activities on a global scale, leading to an increase in both domestic and international collaborative activities.

The growth of international collaborative activities in innovation and R\&D has led researchers from different areas to investigate the underlying motives for these kinds of agreements. Main contributions come from the international management literature, which is concerned with the strategic aspects of international innovation collaboration, and from economics, which looks at the growth of different forms of international alliances and their underlying motives.

Our paper is closely related to the second of these two strands of literature. We look at factors and firm characteristics that influence firms' decision to collaborate with foreign partners on their innovation and R\&D activities. A special feature of our paper is that we look at firms in two different countries rather than at a single one like in most of the existing literature. To be more precise, we compare a very export-oriented country which has an established hitech industry, Germany, with a country which has a negative international trade balance, where most exports come from labour-intensive sectors and which sees its strengths in the services sector, Portugal. Comparing Germany and Portugal is interesting because the two countries exhibit similarities with respect to 
cooperation but differ with respect to the share of innovative firms and, of course, in their size and location within Europe.

Using a bivariate probit model to analyse firm-level data from the third Community Innovation Surveys (CIS III) for the two countries, we find that the characteristics of firms cooperating with foreigners in both countries are quite similar. International activities other than cooperation, firm size and the importance of protection methods for knowledge have a positive influence in both countries on the decision to cooperate with foreign partners. Some differences remain, however: In Germany, exporters are more likely to cooperate with foreign partners than non-exporters, whereas in Portugal this is not the case. 


\title{
International cooperation on innovation: empirical evidence for German and Portuguese firms
}

\author{
Pedro Faria ${ }^{1}$ \\ Tobias Schmidt ${ }^{2}$
}

\begin{abstract}
In this paper we investigate the factors that lead firms to cooperate with partners from foreign countries on innovation activities. Portuguese and German data from the harmonised Community Innovation Survey (CIS III) allow us to compare innovation cooperation behaviour of private firms in the two countries. Using a bivariate probit model, we show that the characteristics of firms cooperating with foreigners in both countries are quite similar. International activities other than cooperation, firm size and the importance of protection methods for knowledge have a positive influence in both countries on the decision to cooperate with foreign partners. Some differences remain, however: In Germany, exporters are more likely to cooperate with foreign partners than non-exporters, whereas in Portugal this is not the case.
\end{abstract}

Keywords: International cooperation, Innovation, CIS III, Germany, Portugal 1 IN+ Center for Innovation, Technology and Policy Research - Instituto Superior Técnico, Technical University of Lisbon, Av. Rovisco Pias 1049-001 Lisboa, Portugal, pedro.faria@dem.ist.utl.pt, Tel.: +351-21-841-7787, Fax: ++351-21-849-6156

2 Deutsche Bundesbank, Economic Research Centre, Wilhelm-Epstein-Str. 14, D-60431 Frankfurt am Main, Germany, Tobias.Schmidt@bundesbank.de, Tel.: +49-69-95663730. At the time most of this article was written, Tobias Schmidt, was with the Department of Industrial Economics and International Management, ZEW Mannheim, Germany.

Disclaimer: Discussion Papers represent the authors' personal opinions and do not necessarily reflect the views of the Deutsche Bundesbank or its staff. 


\section{$1 \quad$ Introduction}

Driven by more complex innovation projects and ever shorter innovation and product-life cycles, firms are faced with a demand for knowledge they cannot satisfy with their internal resources alone. "Tapping external sources of knowhow becomes a must” (Tsang, 2000: 225). Firms thus have to look for partners for their innovation projects, which has led to an increase in the number innovation cooperations, documented among others by Hagedoorn (2002) and the OECD (OECD, 1986).

The globalisation of firms' activities has contributed to the pressure to become more innovative and to conduct $\mathrm{R} \& \mathrm{D}$ and innovation activities on a global scale, leading to an increase in both domestic and international collaborative activities. With this increase, the type and structure of collaborations and partnerships between domestic and foreign partners has changed. While, in the past, international R\&D and innovation alliances were mostly equity-based alliances, like joint-ventures, looser forms of collaboration between partners from different countries have emerged in recent years. Actually, most of the growth in international collaborative activities can be attributed to these looser and more flexible forms of collaboration between partners from different countries (Narula and Hagedoorn, 1999).

The increasing collaborative activities of firms and the exchange and flows of knowledge associated with them have attracted the interest of policymakers. Some national and European-level financing institutions have established cooperation, and, in particular, international cooperation, as an essential condition for giving support to firms in the area of innovation and research and development in order to foster the flow of knowledge between national innovation systems (Czarnitzki and Fier, 2003; Kingsley and Malecki, 2004; Eickelpasch and Fritsch, 2005). 
The growth in international collaborative activities in innovation and $R \& D$ has led researchers from different areas to investigate the underlying motives for these kinds of agreements. Main contributions come from the international management literature, which is concerned with the strategic aspects of international innovation collaboration, and from economics, which looks at the growth of different forms of international alliances and their underlying motives. Our paper is closely related to the second of these two strands of literature. We look at the factors and firm characteristics that influence firms' decisions to collaborate with foreign partners on their innovation and R\&D activities. The paper contributes to the existing literature in two ways. First, we use a large scale survey to tackle the question at hand and not a case study approach. Additionally, the data we have also allow us to take the looser forms of collaboration into account and focus not only on equity joint-ventures.

Second, we compare a very export-oriented country which has an established hi-tech industry, Germany, with a country which has a negative international trade balance, where most exports come from labour-intensive sectors and which sees its strengths in the services sector, Portugal. Given these differences, our firm-level data from Portugal and Germany will allow us to analyse the international innovation cooperation behaviour of firms in an economy that is highly involved in foreign product markets as opposed to a country that has less experience and less established links with foreign partners.

Comparing Germany and Portugal is also interesting because the two countries exhibit some interesting similarities with respect to cooperation but differ with respect to the share of innovative firms and, of course, in their size and location within Europe. What is most relevant to our study is the innovation behaviour, however. According to the Eurostat publication "Innovation in Europe" (Eurostat, 2004), 54\% of all German firms with ten or more employees introduced product or process innovation between 1998 and 2000. In Portugal, the figure is 10 percentage points smaller at $44 \%$. However, the percentage of 
innovators that cooperated is quite similar in both countries at $16.8 \%$ in Portugal and $17.4 \%$ in Germany. 1 The structure of innovation cooperation with respect to domestic and foreign partners is also quite similar in both countries. Between 1998 and 2000, about 14\% of German firms cooperated with partners within Germany and about 7\% with partners in the EU. The respective figures for Portugal are 17\% and 5\% (Eurostat, 2004). It looks like the innovators in both countries are quite similar with respect to their innovation cooperation behaviour, despite the different structure of their respective economies. In the empirical part of the paper, we analyse whether this similarity is just a phenomenon at the aggregate level or whether it also shows up in the factors that influence the decision to cooperate with domestic and foreign partners on innovation activities.

The paper is structured as follows: In the following section, we review the literature on innovation cooperation, with a focus on cooperation with foreign partners. This will be followed, in section 3, by a description of the Portuguese and German datasets used in the empirical part of the paper. Section 3 will also provide information on the construction of our main variables, descriptive statistics and the econometric model. In section 4, we present our estimation results for the two countries before we draw some conclusions and discuss some policy advice in section 5 .

1 Over the period 2001-2003, a similar structure emerges with respect to innovation cooperation: $16 \%$ of German innovation active firms cooperated on innovation activities and 19\% of Portuguese innovation-active firms (Eurostat, 2007a and 2007b). The gap between the share of innovative firms widened to 24 percentage points for the same period (Germany: 65\%; Portugal: 41\%). 


\section{Literature review}

The increased complexity of knowledge processes, which are the backbone of the creation of new technologies, leads firms to search for valuable knowledge and skills externally in order to complement their own capabilities (Becker and Dietz, 2004). Since the 1980s, the increasing instability of the competitive environment, with shorter product and technological life cycles, has forced firms to reconsider their innovation strategy in order to widen their technology base (Nijssen et al., 2001). In this context, cooperation has gained an important role in the innovation process at the firm level, given that innovation cooperation activities are considered an efficient means of industrial organisation of complex R\&D and innovation processes. As described by Rosenfeld (1996) and Hagedoorn et al. (2000), not only multinationals firms but also small and medium-sized firms are engaging in more and tighter relationships with other companies to achieve greater economies of scale, market strength, or exploit new opportunities. These joint activities can take several forms, both formal and informal, such as co-marketing, co-production, shared resources, or joint development (Bönte and Keilbach, 2005). As far as innovation activities are concerned, the boundaries of innovation are shifting from a situation where firms perform R\&D activities mainly internally (Mowery, 1983; Nelson, 1990) to a reality where corporate partnering, collaboration and external sourcing in $R \& D$ are used. In this new context, internal and external sourcing of innovation inputs, as $\mathrm{R} \& \mathrm{D}$, are not seen as substitutes, but as complements, since internal innovation activities are not incompatible (and can be synergetic) with agreements with other firms, research agreements with universities, investments in the capital stock of new firms, and acquisition of small firms (Arora and Gambardella 1990; Cassiman and Veugelers, 2002; Adams and Marcu, 2004).

Cooperation activities with other firms or institutions are seen by firms as an opportunities to access complementary technological resources (as skill sharing), for faster development of innovations, to improve market access, to realise 
economies of scale and scope, and to share costs and spread risk (see, for example,. Hagedoorn, 1993; Glaister and Buckley, 1996; Narula and Hagedoorn, 1999; Cassiman and Veugelers, 2002; Sakakibara, 1997; Miotti and Sachwald, 2003, Aschhoff and Schmidt, 2006). Cooperation activities are usually characterised by intensive knowledge exchange and mutual learning, basically by combining complementary assets and building synergies (Dachs et al., 2004; Becker and Dietz, 2004). In other words, since innovation-related cooperative agreements favour knowledge accumulation that might be converted into new technological and organisational innovations, the firms' decision to cooperate opens up the range of their technological options (Mowery et al., 1998; Caloghirou et al., 2003). As argued by Gomes-Cassares et al. (2006), firms enrolled in cooperation activities or alliances are involved in denser knowledge flows than non-allied firms.

The classic perspective for analysing the decision to cooperate is to see it as an equilibrium between achieving a high level of knowledge flow and the protection of internal knowledge from leaking out, ie the internalisation of spillovers (see, for example,. D’Aspremont and Jacquemin, 1988; Kamien et al., 1992; de Bondt and Veugelers, 1991; Belderbos et al., 2004; Kaiser, 2002; Cassiman and Veugelers, 2002). Only firms that can protect their vital information are willing to engage in cooperative agreements, an issue which may be less present in cooperative agreements with research institutes and universities than in cooperation with other firms (Belderbos et al., 2003). In other words, cooperation in innovation activities can be analysed as a trade-off between spillovers: firms generate and receive spillovers to and from their cooperation partners. Therefore, firms must manage the external information flows in order to maximise the incoming spillovers from partners and non-partners while, at the same time, control the spillovers to non-partners.

A crucial role in that respect is played by a firm's absorptive capacity, ie its ability to "identify, assimilate and exploit knowledge from the environment" 
(Cohen and Levinthal, 1989: 569). Firms can try to increase the extent of incoming spillovers both within cooperative agreements and from the environment in general by investing in "absorptive capacity". The higher a firm's absorptive capacity, the more able it should be to access and implement a larger amount of external knowledge (Cohen and Levinthal 1989, 1990). Put differently, as argued by Cohen and Levinthal (1989), external knowledge is more effective for the innovation process when the firm engages in its own R\&D. The capacity of firms to take advantage of knowledge generated elsewhere has a positive effect on the probability of being a successful innovator and is positively associated with the decision to undertake formal research collaboration with other firms and institutions (Abramovsky et al., 2005; Bayona et al., 20012). Per se the effect on the cooperation decision is unclear, however, since higher absorptive capacity can make a firm less likely to cooperate because it can obtain access to external knowledge without cooperating.

Other factors that have been argued to influence a firm's cooperation decision include

- public support (Abramovsky et al., 2005; Negassi, 2004; Busom and Fernandez-Ribs, 2004)

- export activities (Dachs et al., 2004; Busom and Fernandez-Ribas, 2004)

- size (Röller et al., 1997; Link and Bauer, 1987; Fritsch and Lukas, 2001)

- industry (Dodgson, 1994; Tether, 2002)

\section{International cooperation}

Globalisation has contributed to a growing number of international R\&D and innovation partnerships (see, for example,. Palmberg and Pajarinen, 2005). Luo (2004) states that the growth of international competition and cooperation is a

2 The literature that finds a positive effect of own R\&D on the probability of collaboration can also be seen as evidence that absorptive capacity has a positive influence on the likelihood of collaboration (eg Fritsch and Lukas, 2001; Fontana et al., 2005), since absorptive capacity is usually represented by a measure of in-house R\&D activities in empirical models (see Schmidt, 2005 for a review). 
natural outcome of the expansion of firms into new markets and countries since this process makes firms face new realities and challenges. Some of the high costs of managing international projects (von Zedtwitz and Gassmann, 2002) have been reduced by the availability and wide diffusion of new information technologies (Li and Zhong, 2003). Associated reductions in communication costs and increases in the potential to coordinate activities across countries have certainly contributed to the boom of international R\&D cooperation.

The motives for cooperating on innovation in general are also potential motives for international R\&D and innovation cooperation. However, there are also some specific motives for entering into international cooperative agreements. Glaister and Buckley (1996) analyse UK firms' international cooperation behaviour (in general and not just related to $R \& D$ ) and show that motives related to technology development, like sharing of $R \& D$ costs and exchange of complementary technology, are more important for cooperation with domestic partners than for cooperation with international partners. The opposite is true of market development motives, such as faster entry into markets, conforming to foreign government policies or facilitating international expansion. Glaister and Buckley's (1996) show that R\&D cooperation motives are similar for international and national partners.

Von Zedtwitz and Gassmann (2002) take a similar approach to analysing international cooperative agreements. Using a database of 81 companies representing 1,021 R\&D sites, they stress the significance of two main internationalisation drivers in R\&D: access to local science and technology sources, and access to local markets and customers. Von Zedtwitz and Gassmann's (2002) findings that technology-intensive firms are trying to exploit location-specific innovation advantages through the internationalisation of their $\mathrm{R} \& \mathrm{D}$ activities and are thus able to cope with the increasingly globalised environment, can serve as an explanation for Glaister and Buckley's (1996) result. Firms no longer look for partners, say,. to share R\&D costs within their 
country only, they also consider firms outside of their country, leading to the observation that the motives for both types of R\&D cooperation are similar.

Palmberg and Pajarinen (2005) focus on the benefits of foreign R\&D cooperation comparing non-equity international partnerships with FDI and equity-based international partnerships. They find that non-equity international partnerships are a mean for firms "to simultaneously be present, source knowledge and compete in multiple countries and regions without the liabilities associated with FDI or joint ventures” (p. 3). Similarly, von Zedtwitz and Gassmann (2002) conclude that complete integration of globally dispersed R\&D activities can produce high coordination and social costs, which drive firms to invest in local product adaptation and in foreign science clusters, usually through looser forms of innovation cooperation.

Another benefit of setting up international cooperative agreements is a potential increase in the competitiveness of the firm. Some empirical evidence stresses that dispersed R\&D activities may contribute to firms' competitiveness when compared with centralised R\&D operations since it is an opportunity to take advantage of host-country scientific inputs and reduce the uncertainty in unfamiliar business environments (Li and Zhong, 2003).

A different explanation for the growing number of international cooperation agreements has been presented by Narula and Hagedoorn (1999). They argue that the fact that few firms have resources to duplicate value chains in different locations has led to more cooperations.

Finally, the involvement of public authorities through support systems can be expected to have an impact on the willingness of firms to engage in $R \& D$ cooperation across borders. In the European Union, for example, many funding schemes explicitly require firms to cooperate in order to gain access to funds for R\&D and innovation projects. 
In summary, access to complementary foreign knowledge and markets and a reduction or sharing of $\mathrm{R} \& \mathrm{D}$ costs seem to be the main drivers of international cooperation.

The review of the existing literature and the weighted figures for innovation cooperation and innovation activities presented in the introduction stress the importance of addressing the issue of the identification of the determinants behind the firm-level decision of being part of international cooperation in innovation. In this context, we address, in the empirical part of the paper, several questions that are raised when looking to this reality:

- Are the determinants of innovation cooperation similar in Portugal and Germany or do differences with respect to the international relationships of firms between Portugal and Germany lead to differences in the factors that influence innovation cooperation with foreign partners?

- Are the determinants of innovation cooperation with domestic partners also determinants of international innovation cooperation? 


\section{Data, construction of the variables and empirical framework}

For the empirical part of the study we use data from the Community Innovation Survey III (CIS III), which was undertaken by the member states of the European Union in 2001. The survey collects data on the innovation activities of firms in each country from both the manufacturing and the service sector. Its design, questions, concepts and the definitions used are based on the Oslo Manual's second edition (OECD, 1992). The questionnaire itself and the methodology are harmonised across the countries, making comparisons between the results in different countries possible. Some minor differences exist nonetheless, as countries are allowed to add questions to their questionnaire and to cover firms that are smaller than the threshold (ten employees) or belong to industries outside the core coverage of NACE classifications.

The latter is the case for the German CIS III survey, which is part of a larger activity in collecting data on the innovation behaviour of private firms in Germany ("Mannheim Innovation Panel”) through an annual innovation survey.3 This annual survey is conducted by the Centre for European Economic Research (ZEW) on behalf of the German Federal Ministry of Education and Research. The German CIS III covers firms with five or more employees and includes, for example, the retail sector which is not part of the core NACE coverage of the CIS. The sample is also stratified by region (East Germany and West Germany) in addition to size and industry. The questionnaire is fully in line with the Eurostat recommendations.

The Portuguese questionnaire is mainly a translation of the harmonised Eurostat questionnaire, but includes some additional questions. Nevertheless, and owing to the experience of CIS II, a more comprehensive design of the questionnaire

3 For a more detailed description of the Mannheim Innovation Panels and the German CIS III, see Janz et al. (2001) and Rammer et al (2005a). 
was developed with several notes and examples shown along with the questionnaire to make it easier for the respondent to understand the questions. 4

To make the results of the surveys and our econometric analysis in the two countries comparable, all variables were constructed in the same way, which was an easy task given the harmonised survey questionnaire. Additionally, firms with fewer then ten employees were omitted from the German dataset and the NACE classification included in the German survey were brought into line with those covered in Portugal.5

Since most of the questions in the survey have to be answered only by innovative firms, ie firms that have introduced at least one product or process innovation between 1998 and 2000 or had ongoing innovation activities, we restricted our sample to this group of firms.

\section{Construction of the variables and descriptive statistics}

On the next page we describe the construction of the variables included in our empirical model. Our estimation strategy is to estimate a system of equations with indicators of foreign and domestic cooperation as dependent variables and a number of potential determinants of international innovation cooperation and general firm characteristics as independent variables. The choice of independent variables for the empirical model is based on the literature review in section 2 .

\section{Dependent variables}

Two dependent variables are constructed from a matrix-type question on R\&D and innovation cooperation. 6 Each innovating firm was asked to indicate if it had “any cooperation arrangements during 1998-2000” (Eurostat CIS III Questionnaire). The question includes a definition of innovation cooperation:

\footnotetext{
4 Details of the way in which the survey was conducted in Portugal may be found in Bóia (2003) ,following the work done by Conceição and Ávila (2001) for the CIS II.

5 See Table 3 in the Appendix for details on the industries included.

6 For a more detailed description of the construction of the dependent and independent variables, see Table 3 in the appendix.
} 
"Innovation cooperation means active participation in joint $R \& D$ and other innovation projects with other enterprises or non-commercial institutions. It does not necessarily imply that both partners derive immediate commercial benefit from the venture. Pure contracting out of work, where there is no active collaboration, is not regarded as cooperation.” (Eurostat CIS III Questionnaire) If the firm answered 'yes', it was asked to indicate with which partners it had cooperated. Potential partners were combinations of the role of the partner (for example, other firms within the same group of firms7, customer, supplier, competitor, consultants, public institutions) and their location (domestic, EU/EFTA, USA, Japan and rest of the world). We used this information to construct our dependent variables. The first variable indicates whether the firm has cooperated with at least one domestic partner (cod) and the second indicates if the firm has cooperated with at least one foreign partner (coforeign). Firms can of course have cooperated on R\&D and innovation activities with both domestic and foreign partners. In this case, both variables will be one. In Portugal, 205 (26\%) innovative firms in the sample are cooperating, the corresponding figure in Germany is 478 (32\%). As Table 1 shows, 459 firms (96\% of cooperating firms) in Germany are collaborating at least with domestic partners and 181 (38\%) with foreign partners. In Portugal, the first group consists of 175 firms (85\%) and the second of 109 firms (51\%). Splitting up the cooperating firms into exclusive groups reveals that 96 Portuguese firms (47\% of all cooperating firms) co-operate only with domestic partners, 30 (14\%) only with foreign partners and 79 (39\%) with both domestic and foreign partners. In Germany, the respective figures are 297 (62\%), 19 (4\%) and $162(34 \%)^{8}$.

7 Firms only cooperating with partners from their own group were excluded from the analysis for two reasons: First, cooperation within a group is certainly different from cooperating with external partners, for example,. with respect to trust and, second, only firms belonging to a group can cooperate within their group, while all the other partners can be chosen by all firms.

8 Comparing these figures with the weighted results published by Eurostat (Eurostat, 2004 - see also introduction), cooperating firms and firms cooperating with foreign partners are over-represented in our sample. However, our sample is different from the Eurostat sample, since we excluded some industries from our analysis. 
Table 1 Descriptive statistics (means) for Portuguese and German samples

\begin{tabular}{|c|c|c|c|c|c|c|}
\hline & \multicolumn{3}{|c|}{ Germany } & \multicolumn{3}{|c|}{ Portugal } \\
\hline & Sample & $\operatorname{cod}=1$ & coforeign $=1$ & Sample & $\operatorname{cod}=1$ & coforeign $=1$ \\
\hline \multirow{2}{*}{$\begin{array}{l}\text { Number of observations } \\
\text { in } \% \text { of total sample }\end{array}$} & 1510 & 459 & 181 & 774 & 175 & 109 \\
\hline & - & $30 \%$ & $12 \%$ & - & $23 \%$ & $14 \%$ \\
\hline \multirow{2}{*}{ Exports status (1998) } & 0.697 & $0.756^{a}$ & $0.862^{a}$ & $0.787^{b}$ & $0.840^{b}$ & $0.899^{a}$ \\
\hline & [0.459] & {$[0.430]$} & {$[0.346]$} & [0.410] & {$[0.368]$} & {$[0.303]$} \\
\hline \multirow{2}{*}{ Domestic group dummy } & 0.162 & 0.152 & 0.138 & $0.269^{b}$ & $0.469^{a b}$ & $0.404^{a b}$ \\
\hline & {$[0.368]$} & {$[0.360]$} & {$[0.346]$} & [0.444] & {$[0.500]$} & {$[0.493]$} \\
\hline \multirow{2}{*}{ Multinational dummy } & 0.103 & 0.126 & $0.160^{\mathrm{a}}$ & $0.134^{b}$ & 0.143 & $0.266^{a b}$ \\
\hline & [0.304] & [0.333] & [0.368] & [0.341] & {$[0.351]$} & {$[0.444]$} \\
\hline \multirow{2}{*}{ Skills dummy } & 0.503 & $0.678^{a}$ & $0.696^{a}$ & $0.348^{b}$ & $0.491^{a b}$ & $0.505^{a b}$ \\
\hline & {$[0.500]$} & [0.468] & [0.461] & {$[0.476]$} & {$[0.501]$} & {$[0.502]$} \\
\hline \multirow{2}{*}{ Engagement $R \& D$ dummy } & 0.643 & $0.882^{a}$ & $0.912^{a}$ & 0.609 & $0.794^{a b}$ & $0.881^{a}$ \\
\hline & [0.479] & [0.323] & [0.285] & [0.488] & {$[0.405]$} & {$[0.326]$} \\
\hline \multirow{2}{*}{ Innovation intensity } & 0.068 & $0.102^{a}$ & $0.119^{\mathrm{a}}$ & $0.057^{b}$ & $0.058^{b}$ & $0.052^{b}$ \\
\hline & [0.109] & [0.144] & {$[0.163]$} & [0.101] & {$[0.083]$} & {$[0.072]$} \\
\hline \multirow{2}{*}{ Public funding for innovation dummy } & 0.358 & $0.658^{a}$ & $0.624^{\mathrm{a}}$ & 0.351 & $0.571^{a b}$ & $0.532^{a}$ \\
\hline & {$[0.480]$} & {$[0.474]$} & {$[0.486]$} & [0.478] & {$[0.496]$} & {$[0.501]$} \\
\hline \multirow{2}{*}{ Incoming spillovers } & 0.550 & $0.601^{\mathrm{a}}$ & $0.620^{\mathrm{a}}$ & $0.414^{b}$ & $0.492^{a b}$ & $0.488^{a b}$ \\
\hline & [0.268] & {$[0.253]$} & [0.239] & [0.305] & {$[0.306]$} & {$[0.320]$} \\
\hline \multirow{2}{*}{ Outgoing spillovers } & 0.244 & $0.356^{\mathrm{a}}$ & $0.427^{\mathrm{a}}$ & $0.055^{b}$ & $0.076^{a b}$ & $0.096^{a b}$ \\
\hline & [0.235] & {$[0.237]$} & {$[0.217]$} & [0.072] & {$[0.078]$} & {$[0.089]$} \\
\hline \multirow{2}{*}{$\begin{array}{c}\text { Medium firm dummy } \\
(50<=\text { employees }<250)\end{array}$} & 0.352 & 0.333 & 0.293 & $0.416^{b}$ & 0.417 & $0.459^{b}$ \\
\hline & [0.478] & [0.472] & {$[0.456]$} & [0.493] & [0.495] & {$[0.501]$} \\
\hline \multirow{2}{*}{$\begin{array}{l}\text { Large firm dummy } \\
\text { (employees=> 250) }\end{array}$} & 0.287 & $0.364^{a}$ & $0.486^{a}$ & $0.209^{b}$ & $0.366^{a}$ & $0.413^{\mathrm{a}}$ \\
\hline & [0.452] & [0.482] & {$[0.501]$} & [0.407] & [0.483] & [0.495] \\
\hline \multirow{2}{*}{$\begin{array}{l}\text { Medium-Tech manufacturing firm } \\
\text { dummy }\end{array}$} & 0.399 & 0.420 & 0.425 & $0.310^{b}$ & $0.326^{b}$ & 0.376 \\
\hline & {$[0.490]$} & [0.494] & {$[0.496]$} & [0.463] & {$[0.470]$} & {$[0.487]$} \\
\hline \multirow{2}{*}{ Hi-Tech manufacturing firm dummy } & 0.256 & $0.157^{\mathrm{a}}$ & $0.160^{\mathrm{a}}$ & $0.052^{b}$ & 0.063 & 0.083 \\
\hline & {$[0.437]$} & [0.364] & {$[0.368]$} & [0.222] & {$[0.243]$} & {$[0.277]$} \\
\hline \multirow{2}{*}{$\begin{array}{l}\text { Low-Knowledge intensive service } \\
\text { firm dummy }\end{array}$} & 0.117 & 0.092 & $0.061^{\mathrm{a}}$ & 0.130 & 0.097 & $0.064^{\mathrm{a}}$ \\
\hline & [0.321] & [0.289] & {$[0.240]$} & [0.337] & {$[0.297]$} & {$[0.246]$} \\
\hline \multirow{2}{*}{$\begin{array}{l}\text { Knowledge-intensive service firm } \\
\text { dummy }\end{array}$} & 0.256 & 0.261 & 0.276 & $0.177^{b}$ & 0.234 & 0.211 \\
\hline & {$[0.437]$} & [0.439] & [0.448] & [0.382] & [0.425] & {$[0.410]$} \\
\hline \multirow{2}{*}{ Eastern Germany dummy } & 0.327 & 0.370 & $0.227^{\mathrm{a}}$ & - & $=$ & - \\
\hline & [0.469] & [0.483] & {$[0.420]$} & - & - & _. \\
\hline
\end{tabular}

a) significantly different from sample mean at least at $95 \%$ level

b) significantly different from mean in Germany at least at $95 \%$ level 


\section{Independent variables}

To structure the analysis we include three groups of potential determinants of international innovation cooperation and characteristics of firms in our empirical model.

A first group of variables is meant to capture the link between innovation cooperation and firms' other links with foreign countries. This group includes the export status of the firm (exports) in 19989 and an indicator variable taking the value one if the firm belongs to a multinational group with its headquarters in a foreign country (multinational) or not. As the descriptive statistics of our sample show, the percentage of both exporters and firms belonging to a multinational group is higher in the group of firms cooperating with foreigners than in the sample. This is the case for Portugal and Germany.

While the first group provides some specific factors that should mainly influence the decision to cooperate with a foreign partner on innovation activities, the following section will describe the construction of the variables that can be assumed to influence the decision to cooperate with both domestic and foreign partners. That said, firms selling goods and services on an international market might also be more likely to cooperate with domestic partners than non-exporters, because they face greater competition than nonexporters or because they have to develop more innovative products to be successful on foreign markets.

The second group of variables is related to the innovation activities of the firm. We try to capture a variety of innovation activities, from variables related to a firm's absorptive capacity to variables capturing the innovation strategy of firms. Absorptive capacity is measured along two dimensions: in-house $R \& D$ activities (Rnd) and the skill level of firms' employees (skills). Information on these

9 We included the export status in 1998 and not 2000 to reduce a potential endogeneity bias that may exist between exports and international innovation cooperation. See Ebling and Janz (1999) for a discussion of the endogeneity of exports and innovation. 
dimensions of absorptive capacity can be taken directly from questions included in both innovation surveys: Rnd is constructed based on a question that asks firms to indicate whether they had any continuous or occasional R\&D activities between 1998 and 2000. A dummy for an above-average percentage of employees with a higher education degree is constructed using a question on the skill levels of employees. This variable takes the value one if the firm has a higher share than the median firm in the country.

That absorptive capacity has a positive effect on innovation cooperation in general has been established by the previous literature. Our descriptive statistics support this finding. In Portugal and Germany cooperating firms (regardless of the nationality of their partners) have a larger percentage of firms with an aboveaverage percentage of high skill labour and $R \& D$ performers than the average firm in the two samples. Surprisingly enough, the innovation intensity is higher for cooperating firms than for noncooperating firms in Germany only.

We also include variables measuring the innovation intensity of a firm, ie the share of innovation expenditure in sales (inno_int). Innovation expenditure is taken directly from a question on different types of innovation activities in 2000, including in-house $\mathrm{R} \& \mathrm{D}$, external $\mathrm{R} \& \mathrm{D}$, acquisition of machinery and acquisition of knowledge for innovation, training for innovations and preparation of the market for the introduction of innovations.

We include the innovation intensity also as a squared term (inno_int2) to allow for a non-linear relationship between innovation expenditure and the likelihood of collaborating with domestic or foreign partners. Firms spending more funds on innovation activities relative to their turnover may be less likely to collaborate on innovation activities in general, because they are at the frontier and cannot find adequate partners or because they are able to satisfy their needs with their own in-house innovation activities.

Innovation cooperation is certainly part of the overall innovation strategy of the firm. As Cassiman and Veugelers (2002) and many other authors using their 
empirical model have shown, the generation and prevention of knowledge spillovers is particularly important in that respect. We include two measures of knowledge spillovers: incoming knowledge spillovers (spill_in) and outgoing spillovers (spill_out). The first measure is constructed from a question on information sources a firm uses for its innovation activities. It represents the importance a firm assigns to publicly available information from professional conferences, meetings, journals, exhibitions and trade fairs. Usually this variable is assumed to have a positive effect on innovation cooperation in general. The argument is that firms assigning a great importance to external knowledge have an incentive to cooperate in order to internalise spillovers. Given the construction of the variable, it is also conceivable that it has a negative impact on the likelihood of innovation cooperation. If the firm assigns major importance to freely available knowledge it might be less inclined to cooperate simply because it can obtain the knowledge it needs without cooperating on $R \& D$ and innovation.

The prevention of spillovers is measured indirectly: the higher the importance of patents and secrecy the lower will be outgoing spillovers (see Schmidt, 2006). Moreover, the outgoing knowledge spillovers variable also gives an indication of firms' strategies with respect to the protection of valuable firm-specific competitive advantages. If firms assign a high value to protection methods they might be less likely to cooperate because they do not want to expose their valuable assets to third parties. Our descriptive statistics point in another direction, however. Cooperating firms assign greater importance to both incoming and outgoing spillovers than noncooperating firms in both countries do. This points to a potential endogeneity problem. Firms may be more likely to use protection methods if they cooperate in order to protect their knowledge from spilling over to the cooperation partner.

A special and distinct part of the innovation activities of a firm is public funding. As has been mentioned in the literature review, public funding may be a 
factor influencing a firm's cooperation decision. We thus include a dummy variable, which takes the value one if the firm has received any public funding for its innovation activities from either national or international authorities.

Finally, some more basic firm characteristics are included in our empirical model on the right-hand side of the equation. We include two size dummies, one for firms with 50 to 249 employees (size2) and one for large firms with 250 and more employees (size3) with firms with ten to 49 employees being the reference category. The industry group a firm belongs to is represented by five industry groups of dummies that are constructed in accordance with the OECD classification of knowledge-intensive services and manufacturing industries (for details see Table 3 in the appendix). The reference category is low-tech manufacturing which comprises firms in NACE 15 to 22, 26 and 37.

Even though we excluded firms which are only cooperating within their own group, we still control for the being part of a group by including a dummy for multinationals and one for domestic groups. Belonging to a group allows firms to gain some experience of activities distributed over several locations and joint $R \& D$ activities with firms from their group. This should have a positive influence on the ability to handle and manage cooperative agreements and should thus lead to a higher probability of collaborating on R\&D with all kinds of partners.

Almost all studies on the innovation behaviour of German firms using data from the Mannheim Innovation Panel (both econometric and descriptive), take into account whether the firm is from East or West Germany. They frequently find a significant influence of the location on all kinds of innovation activities (eg Sofka and Schmidt, 2004, Rammer et al., 2005b). In order to take this into account we also include a dummy variable for East Germany in the estimations on the German dataset. The percentage of firms from East Germany in the group 
of firms cooperating with foreign partners is about $23 \%$ and significantly lower than in the sample 10.

As far as these more general firm characteristics are concerned, our descriptive statistics show that the firms cooperating with foreign partners are, on average, larger than non-cooperating firms in both Portugal and Germany. In Germany, they are also more often from hi-tech manufacturing industries, while they are not in Portugal. In Portugal, firms belonging to a multinational group are significantly more often cooperating with foreign partners than non-cooperating firms are.

\section{Comparison of descriptive statistics between Portugal and Germany}

To conclude this section, we look at a few of the differences between the Portuguese and German samples. It is, at first sight, surprising that in the Portuguese sample, the share of exporters is higher than in the German one. Note however, that we are not measuring the volume of exports but the percentage of firm reporting any exports. Except for the share of firms belonging to a group, most of the other values are significantly smaller in Portugal than in Germany, most notably, the already mentioned share of hi-tech manufacturing firms. The comparison of the means reveals that intellectual property protection and other protection methods (outgoing spillover variable) are less important in Portugal than in Germany. This may be a result of different types of innovation and R\&D activities in the two countries. More novel products usually require more protection than imitative innovations. The share of funded firms is not significantly different between Germany and Portugal.

10 To check whether the inclusion of an East Germany dummy influences the results we also estimated the equations for Germany without the east German dummy. All variables that are significant in the tables reported below retain their significance. The only difference is that the skills variable goes from the $95 \%$ to the $90 \%$ level for foreign partners. The coefficients and marginal effects change only slightly. The structure with respect to the marginal effects stays the same both within each equation and across equations. The estimation results without the East German dummy are available upon request. 
The comparison of the means for German and Portuguese firms that cooperate with foreign partners provides some interesting insight as well. The percentage of exporters, $R \& D$ active firms, and founded firms is not significantly different between the two countries. However, we find differences for the means with respect to firms cooperating with domestic partners on innovation activities. This means that the groups of firms only cooperating with foreign partners are quite similar, as are those cooperating with domestic and foreign partners. The percentage of large Portuguese firms cooperating with foreign partners is also similar to the percentage in Germany. This is the case for firms cooperating with domestic partners as well.

\section{Econometric model}

The structure of the data collected with the CIS III surveys on collaboration with foreign partners per se allows the choice of at least two different econometric methods, multinominal logit or bivariate probit. The data could be arranged in a way that three exclusive categories would result, ie only domestic cooperation partners, only foreign cooperation partners and partners from both domains. The multinominal logit model would, however, also imply that the firm takes only one decision on the location of its cooperation partners, which is fairly unlikely, particularly since we look at the behaviour of the firm in general and not at single projects. We think that the decision to collaborate with a partner abroad is taken not once and for all, but for each project or potential collaborative activity separately. Consequently, we decided not to use the multinominal logit estimation procedure, but a bivariate probit model, which takes into account the fact that the decision to collaborate with domestic partners and the decision to cooperate with foreign partners is correlated 11 . This can be achieved by estimating the two decisions simultaneously and allowing the error terms in the two equations to be correlated. What is more, we do not have to split up our

11 In studies on similar topics other authors have also used multivariate probit models (see, for example, Belderbos et al., 2004 or Capron and Cincera, 2004). 
cooperating firms into exclusive combinations of partners nationalities and can test if the decisions are independent of each other or not.

A second issue is selectivity. Only those firms that were involved in innovation cooperations between 1998 and 2000 were asked to provide answers on the location of their partners. This gives rise to a sample selection problem described by (Heckman, 1976; Heckman, 1979). The general idea behind Heckman's model is that the standard OLS or probit estimations are biased if the dependent variable which is supposed to be explained is only observed for a specific group of firms in the sample. The solution proposed by Heckman is to take this selection into account by estimating a two-equation model. However, in order to be able to apply his model one variable would be necessary that only influences the decision to cooperate, but not the choice to cooperate with domestic or foreign partners. Obviously, such a variable does not exist in our data and the Heckman procedure cannot be applied. To arrive at consistent estimates we use a set-up similar to Belderbos et al. (2004) and Capron and Cincera, (2004)12, ie we set our dependent variables to zero for firms that did not cooperate between 1998 and 2000. By applying this procedure we analyse the decision to cooperate with a domestic partner or not to cooperate and the decision to cooperate with a foreign partner or not to cooperate. We shall not be able to address the decision to cooperate on innovation with a given partner conditional on having decided to cooperate on innovation (see Capron and Cincera (2004) for a discussion of these issues). All the independent variables are not affected by this procedure as they are available for cooperating and non-cooperating firms.

12 Belderbos et al. (2004) and Capron and Cincera (2004) use this method to look at cooperation with different partners. Their survey is similar to the one we use, ie the partner is observed only if the firm cooperated. Miotti and Sachwald (2003) restrict their sample to cooperating firms and analyse the decision to cooperate with different partners for this sub-sample without taking selectivity into account. Because Heckman showed that these estimates are biased we decided to employ the method of Belderbos et al. (2004) and Capron and Cincera (2004) in this paper. 
The formal bivariate probit can be defined as

The equation for innovation cooperation with domestic firms is given by

$$
\begin{aligned}
& \operatorname{cod}^{*}=\beta_{1}^{\prime} X+\varepsilon_{1} \\
& \text { with } \operatorname{cod}_{i}= \begin{cases}1 & \text { if } \operatorname{cod}_{i}^{*}>0 \\
0 & \text { otherwise }\end{cases}
\end{aligned}
$$

and the equation for innovation cooperation with foreign firms by

$$
\begin{aligned}
& \text { coforeign }^{*}=\beta_{2}^{\prime} X+\varepsilon_{2} \\
& \text { with } \text { coforeign }_{i}=\left\{\begin{array}{l}
1 \text { if coforeign } \\
0 \text { otherwise }
\end{array}\right.
\end{aligned}
$$

where the correlation of the error terms is not equal to zero:

$\operatorname{Cov}\left(\varepsilon_{1}, \varepsilon_{2}\right)=\rho_{1}$ 


\section{$4 \quad$ Results}

In this section, we first compare our results for innovation cooperation with foreign partners in Portugal and Germany before providing some interpretation for specific variables and effects.

\section{Innovation cooperation with foreign partners in Portugal and Germany}

The estimation results (Table 2) show that in Germany and Portugal the characteristics that influence the probability of a firm cooperating with a foreign partner on innovation activities are quite similar.13 In both countries several variables have a positive and significant effect on cooperation with foreign partners: absorptive capacities - measured by engagement in R\&D, the share of high skilled labour and the innovation intensity - public funding, outgoing spillovers and firm size. The industry to which a firm belongs does not have an additional influence on its cooperation behaviour in both countries. What is also similar across countries is that the marginal effects for these variables are smaller for foreign cooperation than for cooperation with domestic partners when they are significant in both equations.

However, some differences exist between the two countries with respect to the internationalisation variables, export status and being a multinational. These can be explained mainly by country specific factors. In Germany, being an exporter has a positive and significant effect on the probability of cooperating with a foreign partner on innovation projects, whereas in Portugal this variable is insignificant. This can be explained by the fact that Germany has more hi-tech exports than Portugal. It might thus be easier for German firms to find partners for innovation and $R \& D$ cooperation abroad because they sell their product to foreign firms involved in innovation activities. Portugal's exports are relatively

13 We do not discuss here the differences between the countries with respect to cooperation with domestic partners. It is noteworthy, however, that these results are also fairly similar. Two important 
low-tech and thus provide fewer opportunities to collaborate on innovation and R\&D activities. In Portugal, being part of a multinational group with headquarters abroad has a significant effect on the probability of cooperating on innovation activities, while it is insignificant in Germany. This might have to do with the different type of multinationals with subsidiaries in both countries. Multinationals seem to come to Germany to collaborate on innovation activities with the domestic firms instead of being located there to conduct innovation activities in collaboration with partners outside of Germany. In Portugal, by contrast, subsidiaries of multinationals' seem to look for partners outside the country to cooperate on R\&D and innovation activities. Together with the negative balance of trade in Portugal, this might indicate that foreign firms open subsidiaries in the country to boost their sales, but also use Portugal as a base for innovation and R\&D activities with firms in other European countries. One reason may be that they are not able to find appropriate partners within Portugal.

The calculation of conditional marginal effects allows us to separate the factors that influence innovation cooperation in more general terms from those that have a specific influence on foreign cooperation. They will tell us which characteristics lead firms to collaborate with foreign partners on innovation activities, given that they already c-operated with domestic partners.14 Our results show that, for the conditional marginal effects, most of the similarities between the two countries remain.

The export status remains significant in Germany, while it is insignificant in Portugal, and being a multinational is significant in Portugal but not in Germany. This means that the internationalisation of firms' activities has - not surprisingly

differences are that the innovation intensity and the outgoing spillover variable are insignificant in Germany for domestic cooperation but significant in Portugal.

14 Note that the unconditional marginal effects on foreign innovation cooperation compare firms not cooperating or cooperating with domestic firms only with firms cooperating with foreign partners. Some part of the obtained effects may thus be attributed to cooperation in general rather than only foreign cooperation. 
- a positive effect of cooperating with a foreign partner in addition to cooperating with a domestic one.

The skills variable loses significance in both countries as does the public funding variable. This is a surprising result. We would have expected the absorptive capacity of a firm's employees to have an effect on its ability to cooperate and probability of cooperating with foreigners besides its effect on domestic cooperation. The same is true of public funding. Given that we included funding received from European Union authorities alongside funding from regional and national authorities, it is surprising that this variable has no additional effect on international collaboration. Then again, the funding from regional and national authorities accounts for approximately $90 \%$ of total funding in Germany and this type of funding usually has a more local/domestic focus. In addition, firms that receive public funding may be the ones that cooperate with domestic firms and also cooperate with foreign ones.

Two noteworthy differences between the two countries occur when looking at the conditional marginal effects. Innovation intensity remains significant in Germany but becomes insignificant in Portugal. For Portugal, the R\&D status remains positive while it loses its significance in Germany. As far as the first finding is concerned, looking at the domestic cooperative activities helps to explain that difference. In Portugal, domestic innovation cooperation is influenced significantly by innovation intensity, in Germany it is not. The share of turnover spent on innovation activities thus seems to influence the cooperative behaviour of Portugal in a more general sense than in Germany and is not specific to foreign cooperation. The significance of the unconditional marginal effect of the innovation intensity in the foreign cooperation equation for Germany indicates that, for Germany, it is a specific factor. As far as the R\&D engagement dummy is concerned, Portuguese firms which perform R\&D and already cooperate with domestic firms seem to look abroad for potential partners while German firms do not. Again, one of the reasons might be that German 
firms can find suitable partners within Germany (see the positive effect on domestic cooperation) for their R\&D activities, while Portuguese firms have to combine foreign and domestic partners to be successful in their R\&D projects, because they lack an established high-technology industry at home.

In summary, by comparing Germany and Portugal we can identify, despite some differences in the specific variables, a set of characteristics and factors that seems to influence innovation cooperation with foreign partners in a more general sense. These are international activities of firms in areas other than R\&D and innovation, and the importance of intellectual property protection and firm size. We also find some support for a positive influence of highly skilled employees. These factors influence the decision to cooperate on innovation in addition to innovation activities other than cooperation, which, not surprisingly, do have an impact.

\section{Details of the determinants of innovation cooperation with foreign and domestic partners}

So far we have mainly discussed the differences between Portugal and Germany with respect to innovation cooperation with foreign partners. In this subsection we take a closer look at each of the three groups of variables included in our model.

The first group of variables - other links with foreign countries - has been shown to have an influence on innovation cooperation with foreign partners in both Portugal and Germany. The argument presented in the previous section that international activities lead firms to be more active in pursuing collaborative innovation and R\&D activities owing to the added pressure from international competition can, however, only partially be supported with our data. In both countries, international activities have no influence on domestic cooperation.

We find a number of significant positive effects for the second group of variables labelled "innovation activities". In Portugal, all our measures for the 
absorptive capacity of a firm are significant for both cooperation with domestic and with foreign partners. In Germany, the scope of the innovation activities of a firm, measured by innovation intensity, is not significant, but the other two measures are. It indicates that firms which are better prepared to absorb and exploit external knowledge are not just using publicly available knowledge for their innovation process but are also trying to access the knowledge of other firms and institutions by cooperating with them. It might also be part of their knowledge exploitation strategy to cooperate on innovation activities with external partners and combine the knowledge absorbed with tacit knowledge held by the partner. The conditional marginal effect for the indicator most closely related to absorptive capacity (skills) is not significant. Thus, it looks as though absorptive capacity is more generally influencing the decision for or against innovation cooperation, rather than the decision to cooperate with a foreign partner.

$\mathrm{R} \& \mathrm{D}$ involvement and innovation intensity also measure aspects of firms' innovation activities other than absorptive capacity. As discussed above, the findings differ on these variables for Portugal and Germany. R\&D activities and the scope of innovation activities can nonetheless be seen as major drivers of $R \& D$ cooperation. Which type of cooperation they influence needs further investigation and seems to differ between countries.

In the light of the findings that absorptive capacity and knowledge play an important role for the cooperation decision, it is very surprising that the incoming spillover variable is not significant at all. This variable can be seen as a measure of the importance a firm assigns to publicly available sources of knowledge. The reason for the insignificance may be that two opposing effects are at work. The first is that the more knowledge a firm is able to acquire from publicly available sources, the less it will feel the necessity to collaborate in order to gain access to additional knowledge. The second effect is that firms would have an incentive to 
cooperate if the publicly available knowledge is easily absorbed by the firm when it cooperates with other institutions.

The marginal effects of the outgoing spillover variable are significantly positive for foreign cooperation in both countries. The use of protection methods may be a signal to a potential foreign partner regarding the innovative capability of the firm and make it easier for a firm to find a cooperation partner. 15 What is more, if a lot of knowledge is safeguarded by protection methods that inhibit licensing agreements, the only feasible way to access external knowledge may be through innovation cooperation. The former argument may help to explain the insignificance of the marginal effect for cooperation with domestic firms in Portugal, and also the significant effect for Germany. As the descriptive statistics show, German firms assign much greater importance to protection methods than Portuguese firms do. It may thus be important for firms to signal their strength and bargaining power to potential partners with Germany as well, while for cooperation among Portuguese firms, this aspect is not a major concern. To draw strong conclusions from these findings raises problems, however. As other studies have shown (eg Cassiman and Veugelers, 2002) this variable may very well be endogenous. The argument presented in the literature is that firms have to protect proprietary knowledge from use by their cooperation partner and may thus be more likely to assign particular importance to protection methods if they cooperate, compared with a situation in which they do not cooperate.

15 See Penin (2005) and Bureth et al (2006) for a discussion of the role of patents in innovation cooperation. 
Table 2 Marginal effects of bivariats probit estimations

\begin{tabular}{|c|c|c|c|c|c|c|}
\hline & \multicolumn{3}{|c|}{ Germany } & \multicolumn{3}{|c|}{ Portugal } \\
\hline & Domestic & Foreign & Conditional & Domestic & Foreign & Conditional \\
\hline Exports status (1998) & $\begin{array}{l}-0.033 \\
{[0.032]}\end{array}$ & $\begin{array}{c}0.042^{\star * *} \\
{[0.015]}\end{array}$ & $\begin{array}{c}0.144^{\star * *} \\
{[0.043]}\end{array}$ & $\begin{array}{c}0.001 \\
{[0.040]}\end{array}$ & $\begin{array}{c}0.019 \\
{[0.028]}\end{array}$ & $\begin{array}{c}0.055 \\
{[0.079]}\end{array}$ \\
\hline Domestic group dummy & $\begin{array}{c}-0.003 \\
{[0.034]}\end{array}$ & $\begin{array}{l}-0.004 \\
{[0.018]}\end{array}$ & $\begin{array}{l}-0.010 \\
{[0.048]}\end{array}$ & $\begin{array}{l}0.132^{\star \star \star} \\
{[0.042]}\end{array}$ & $\begin{array}{c}0.044 \\
{[0.029]}\end{array}$ & $\begin{array}{c}0.006 \\
{[0.065]}\end{array}$ \\
\hline Multinational dummy & $\begin{array}{c}0.033 \\
{[0.043]}\end{array}$ & $\begin{array}{c}0.011 \\
{[0.021]}\end{array}$ & $\begin{array}{c}0.009 \\
{[0.053]}\end{array}$ & $\begin{array}{c}0.009 \\
{[0.049]}\end{array}$ & $\begin{array}{l}0.108^{\star \star} \\
{[0.046]}\end{array}$ & $\begin{array}{c}0.248^{\star * \star} \\
{[0.085]}\end{array}$ \\
\hline Skills dummy & $\begin{array}{l}0.099^{\star * \star} \\
{[0.029]}\end{array}$ & $\begin{array}{l}0.037^{\star *} \\
{[0.015]}\end{array}$ & $\begin{array}{c}0.044 \\
{[0.041]}\end{array}$ & $\begin{array}{l}0.099^{* *} \\
{[0.039]}\end{array}$ & $\begin{array}{l}0.054^{\star} \\
{[0.028]}\end{array}$ & $\begin{array}{c}0.056 \\
{[0.064]}\end{array}$ \\
\hline Engagement R\&D dummy & $\begin{array}{l}0.142^{\star \star \star} \\
{[0.030]}\end{array}$ & $\begin{array}{l}0.035^{\star *} \\
{[0.017]}\end{array}$ & $\begin{array}{c}0.010 \\
{[0.053]}\end{array}$ & $\begin{array}{l}0.083^{\star \star \star} \\
{[0.032]}\end{array}$ & $\begin{array}{l}0.077^{\star \star \star \star} \\
{[0.022]}\end{array}$ & $\begin{array}{l}0.149^{\star *} \\
{[0.064]}\end{array}$ \\
\hline Innovation intensity & $\begin{array}{c}0.080 \\
{[0.026]}\end{array}$ & $\begin{array}{l}0.257^{2 z} \\
{[0.130]}\end{array}$ & $\begin{array}{l}0.699^{z z} \\
{[0.360]}\end{array}$ & $\begin{array}{l}1.144^{z z} \\
{[0.453]}\end{array}$ & $\begin{array}{l}0.658^{\star \star} \\
{[0.326]}\end{array}$ & $\begin{array}{c}0.798 \\
{[0.886]}\end{array}$ \\
\hline Innovation intensity (square) & $\begin{array}{c}0.270 \\
{[0.449]}\end{array}$ & $\begin{array}{c}-0.143^{z z} \\
{[0.188]}\end{array}$ & $\begin{array}{c}-0.592^{\mathrm{zz}} \\
{[0.541]}\end{array}$ & $\begin{array}{c}-2.556^{\mathrm{zz}} \\
{[1.133]}\end{array}$ & $\begin{array}{c}-1.377 \\
{[0.867]}\end{array}$ & $\begin{array}{c}-1.517 \\
{[2.386]}\end{array}$ \\
\hline $\begin{array}{l}\text { Public funding for innovation } \\
\text { dummy }\end{array}$ & $\begin{array}{c}0.317^{* \star *} \\
{[0.030]}\end{array}$ & $\begin{array}{l}0.084^{\star \star \star} \\
{[0.019]}\end{array}$ & $\begin{array}{c}0.031 \\
{[0.039]}\end{array}$ & $\begin{array}{c}0.194^{\star \star \star} \\
{[0.036]}\end{array}$ & $\begin{array}{l}0.061^{\star *} \\
{[0.025]}\end{array}$ & $\begin{array}{c}-0.002 \\
{[0.058]}\end{array}$ \\
\hline Incoming spillovers & $\begin{array}{c}0.076 \\
{[0.048]}\end{array}$ & $\begin{array}{c}0.032 \\
{[0.025]}\end{array}$ & $\begin{array}{c}0.046 \\
{[0.068]}\end{array}$ & $\begin{array}{c}0.078 \\
{[0.051]}\end{array}$ & $\begin{array}{c}0.034 \\
{[0.036]}\end{array}$ & $\begin{array}{c}0.023 \\
{[0.094]}\end{array}$ \\
\hline Outgoing spillovers & $\begin{array}{l}0.334^{\star \star \star} \\
{[0.059]}\end{array}$ & $\begin{array}{c}0.147^{\star \star \star} \\
{[0.030]} \\
\end{array}$ & $\begin{array}{l}0.214^{\star \star *} \\
{[0.078]} \\
\end{array}$ & $\begin{array}{c}0.254 \\
{[0.207]}\end{array}$ & $\begin{array}{l}0.349^{\star \star} \\
{[0.138]}\end{array}$ & $\begin{array}{l}0.753^{\star \star} \\
{[0.351]}\end{array}$ \\
\hline $\begin{array}{c}\text { Medium firm dummy } \\
(50<=\text { employees }<250)\end{array}$ & $\begin{array}{c}0.534 \\
{[0.032]}\end{array}$ & $\begin{array}{l}0.032^{\star} \\
{[0.019]}\end{array}$ & $\begin{array}{c}0.056 \\
{[0.049]}\end{array}$ & $\begin{array}{l}0.070^{*} \\
{[0.039]}\end{array}$ & $\begin{array}{l}0.088^{* \star \star} \\
{[0.032]}\end{array}$ & $\begin{array}{l}0.172^{\star \star} \\
{[0.076]}\end{array}$ \\
\hline $\begin{array}{c}\text { Large firm dummy } \\
\text { (employees }=>250)\end{array}$ & $\begin{array}{l}0.169 \star \star \star \\
{[0.039]}\end{array}$ & $\begin{array}{l}0.094^{\star \star \star} \\
{[0.026]}\end{array}$ & $\begin{array}{l}0.132^{\star \star} \\
{[0.054]}\end{array}$ & $\begin{array}{l}0.174^{\star \star \star} \\
{[0.059]}\end{array}$ & $\begin{array}{l}0.145^{\star \star \star} \\
{[0.052]}\end{array}$ & $\begin{array}{l}0.185^{\star \star} \\
{[0.092]}\end{array}$ \\
\hline $\begin{array}{l}\text { Medium-Tech manufacturing firm } \\
\text { dummy }\end{array}$ & $\begin{array}{c}0.054 \\
{[0.045]}\end{array}$ & $\begin{array}{c}0.004 \\
{[0.023]}\end{array}$ & $\begin{array}{l}-0.023 \\
{[0.062]}\end{array}$ & $\begin{array}{c}0.048 \\
{[0.040]}\end{array}$ & $\begin{array}{c}0.041 \\
{[0.029]}\end{array}$ & $\begin{array}{c}0.068 \\
{[0.068]}\end{array}$ \\
\hline $\begin{array}{c}\text { Hi-Tech manufacturing firm } \\
\text { dummy }\end{array}$ & $\begin{array}{l}0.145^{\star *} \\
{[0.067]}\end{array}$ & $\begin{array}{c}0.014 \\
{[0.032]}\end{array}$ & $\begin{array}{l}-0.039 \\
{[0.069]}\end{array}$ & $\begin{array}{c}-0.037 \\
{[0.063]}\end{array}$ & $\begin{array}{l}-0.003 \\
{[0.044]}\end{array}$ & $\begin{array}{c}0.029 \\
{[0.122]}\end{array}$ \\
\hline $\begin{array}{l}\text { Low knowledge-intensive service } \\
\text { firm dummy }\end{array}$ & $\begin{array}{l}0.189 * \star \star \\
{[0.065]}\end{array}$ & $\begin{array}{c}0.027 \\
{[0.038]}\end{array}$ & $\begin{array}{l}-0.031 \\
{[0.078]}\end{array}$ & $\begin{array}{l}0.115^{\star} \\
{[0.066]}\end{array}$ & $\begin{array}{c}0.014 \\
{[0.045]}\end{array}$ & $\begin{array}{l}-0.052 \\
{[0.104]}\end{array}$ \\
\hline $\begin{array}{l}\text { Knowledge-intensive service firm } \\
\text { dummy }\end{array}$ & $\begin{array}{c}0.087 \\
{[0.055]}\end{array}$ & $\begin{array}{c}0.032 \\
{[0.032]}\end{array}$ & $\begin{array}{c}0.034 \\
{[0.076]}\end{array}$ & $\begin{array}{c}0.090 \\
{[0.060]}\end{array}$ & $\begin{array}{c}0.035 \\
{[0.041]}\end{array}$ & $\begin{array}{c}0.016 \\
{[0.091]}\end{array}$ \\
\hline Eastern Germany dummy & $\begin{array}{c}-0.005 \\
{[0.029]}\end{array}$ & $\begin{array}{c}-0.047^{\star \star *} \\
{[0.013]}\end{array}$ & $\begin{array}{c}-0.136^{\star * *} \\
{[0.038]}\end{array}$ & $\begin{array}{l}- \\
- \\
\end{array}$ & $\begin{array}{l}- \\
- \\
\end{array}$ & $\begin{array}{l}- \\
- \\
\end{array}$ \\
\hline $\begin{array}{c}\text { Observations } \\
\text { Loglikelihood of biprobit } \\
X^{\wedge} 2 \text { of biprobit } \\
\text { Likelihood-ratio test of rho }=0\end{array}$ & & $\begin{array}{c}1510 \\
-1053.02 \\
435.90 \\
175.34\end{array}$ & & & $\begin{array}{l}774 \\
-549.19 \\
172.40 \\
88.02 * \star \star \\
\end{array}$ & \\
\hline
\end{tabular}

Standard errors in brackets

* significant at 90\%; ** significant at 95\%; ${ }^{* \star}$ significant at $99 \% ;{ }^{2 z}$ jointly significant at the $95 \%$ level All dummy variables: $\mathrm{dF} / \mathrm{dx}$ is for discrete change of dummy variable from 0 to 1 
The last group of variables concerns general firm characteristics. Here we find support for the common finding that larger firms are more likely to cooperate with both domestic and foreign partners than are smaller firms. This can be attributed to the fact that larger firms have more opportunities to cooperate because they have a higher number of innovation projects, which increases the probability that at least one project is performed in cooperation with external partners (see Fritsch and Lukas, 2001). They usually also have more resources to commit to innovation projects performed in collaboration with external partners. For a small firm it may not be feasible to engage in cooperative innovation activities simply because they need all their personnel for in-house tasks.

Belonging to a group of firms and the industry affiliation of a firm only influences domestic innovation cooperation. Only one marginal effect for the industry is significant in each country. Belonging to a domestic group is only significant in Portugal for domestic cooperation. Finally, the Eastern German dummy is negative and significant in Germany, supporting many other studies that find that East and West German firms still differ in their innovation behaviour. 


\section{$5 \quad$ Conclusions}

This paper analyses the decision of firms to cooperate with foreign partners on innovation projects. It compares a very export-oriented country with an established hi-tech industry, Germany, with a country which has more imports than exports and sees its strengths in the services sector, Portugal.

The main conclusion of our analysis is that the determinants of cooperating with a foreign partner on innovation activities are similar in both countries. In other words, the typical international cooperative firm of a small and less developed economy has the same characteristics as the international cooperative firm of a large and more developed economy: above-average absorptive capacities, receiving public funding, higher level of outgoing spillovers and above-average number of employees. It looks as though firms have the same needs and must own similar capabilities to be able to engage in international innovation networks. Supporting investments in absorptive capacities, the growth of firms and the production of knowledge, could thus be policies that promote innovation and internationalisation in both countries.

Our study also shows that cooperation with foreign partners is linked to other international activities of firms in both countries. Here the specific framework of the two nations does play a role. In the export-oriented economy of Germany exporters are more likely to cooperate with foreign partners than non-exporters, whereas belonging to a multinational group of firms does not have a significant impact on the probability of foreign cooperation. In Portugal, a country with a negative international trade balance, the opposite is true.

Future research should complement this study. One possible line of development could be deepening the analysis of the different types of partners, trying to scrutinise whether Portuguese and German firms choose similar or different types of international partners (eg competitors, suppliers or research institutes) to develop innovation collaborations. In addition, comparisons with 
other European countries could provide further insight into the mechanisms behind international cooperation on innovation activities.. Through international collaboration between a researcher from Portugal and Germany we have shown how beneficial international partnerships can be. Further research is necessary to compare the effects of domestic collaboration and international collaboration on various microeconomic as well as macroeconomic outputs.

\section{Acknowledgements}

The authors would like to thank Heinz Herrmann, Francisco Lima, Bettina Peters, Christian Rammer and Wolfgang Sofka for their valuable comments. Tobias Schmidt would like to thank Rui Baptista and Pedro Faria not only for making his study visit in Lisbon possible, but also for making it an enjoyable one. Pedro Faria is grateful to the Portuguese Foundation for Science and Technology (FCT) - POS_C Program - for its financial support. The financial support of the IN+ Center for Innovation, Technology and Policy Research and the Center for European Economic Research (ZEW) is gratefully acknowledged. The research reported in this paper was partly supported by Observatório da Ciência e do Ensino Superior (OCES) [Observatory of Science and Higher Education, Ministry for Science and Higher Education, Portugal]. 


\section{Appendix}

Table 3 Construction of the variables and industry coverage

\begin{tabular}{|c|c|c|}
\hline Variable & Type & Construction \\
\hline \multicolumn{3}{|l|}{ Dependent } \\
\hline Cod & Dummy & $\begin{array}{l}\text { One, if the firm cooperated with domestic partners between } \\
1998 \text { and } 2000 .\end{array}$ \\
\hline Coforeign & Dummy & $\begin{array}{l}\text { One, if the firm cooperated with a foreign partner between } 1998 \\
\text { and } 2000 .\end{array}$ \\
\hline \multicolumn{3}{|l|}{ Independent } \\
\hline Exports & Dummy & One, if the firm had exports in 1998. \\
\hline Group & Dummy & One, if the firm belongs to a domestic group of firms. \\
\hline Multinational & Dummy & $\begin{array}{l}\text { One, if the firm belongs to a multinational group of firms with } \\
\text { headquarters in a foreign country. }\end{array}$ \\
\hline Skills & Dummy & $\begin{array}{l}\text { One, if the firm had a percentage of employees with a higher } \\
\text { education degree in total employment in } 2000 \text { above the } \\
\text { national median (Portugal: approx 10\%, Germany approx 15\%) }\end{array}$ \\
\hline Rnd & Dummy & One, if the firm had any R\&D activities between 1998 and 2000. \\
\hline Inno_int & Share & $\begin{array}{l}\text { Total expenditure on innovation activities as a percentage of } \\
\text { total turnover in } 2000 .\end{array}$ \\
\hline Inno_int2 & Share & Square of inno_int \\
\hline Public & Dummy & $\begin{array}{l}\text { One, if the firm received public funding from domestic or EU } \\
\text { authorities for its innovation activities between } 1998 \text { and } 2000 .\end{array}$ \\
\hline Spill_in & Index & $\begin{array}{l}\text { Sum of importance (number between } 0 \text { (not used) and } 3 \text { (high)) } \\
\text { of professional conferences, meetings and journals and of } \\
\text { exhibitions and trade fairs as sources of innovation. Rescaled } \\
\text { between } 0 \text { (no spillovers) and } 1 \text { (maximum spillovers). }\end{array}$ \\
\hline Spill_out & Index & $\begin{array}{l}\text { Sum of importance (number between } 0 \text { (not used) and } 3 \text { (high)) } \\
\text { of strategic and formal protection methods for innovations } \\
\text { (secrecy, complexity of design, lead-time advantage, patents, }\end{array}$ \\
\hline
\end{tabular}




\begin{tabular}{|c|c|c|}
\hline & & $\begin{array}{l}\text { copyrights, trademarks, registered designs). Rescaled between } 0 \\
\text { (not used) and } 1 \text { (highly important). }\end{array}$ \\
\hline Size1 & Dummy & $\begin{array}{l}\text { One, if the firm had at least ten but fewer than } 49 \text { employees in } \\
2004 .\end{array}$ \\
\hline Size2 & Dummy & $\begin{array}{l}\text { One, if the firm had at least } 50 \text { but fewer than } 249 \text { employees in } \\
2004 \text {. }\end{array}$ \\
\hline Size3 & Dummy & One, if the firm had 250 or more employees in 2004. \\
\hline East & Dummy & $\begin{array}{l}\text { One, if the firm is located in East Germany (only German } \\
\text { sample). }\end{array}$ \\
\hline \multicolumn{3}{|l|}{ Industries } \\
\hline $\begin{array}{l}\text { Low-tech } \\
\text { manufacturing }\end{array}$ & Dummy & One, if firm is from NACE 15-22, 36, 37 \\
\hline $\begin{array}{l}\text { Medium-tech } \\
\text { manufacturing }\end{array}$ & Dummy & $\begin{array}{l}\text { One, if firm is from NACE 23, 24(excl.244), 25-29, 31, 34, } \\
35 \text { (excl.353) }\end{array}$ \\
\hline $\begin{array}{l}\text { Hi-tech } \\
\text { manufacturing }\end{array}$ & Dummy & One, if firm is from NACE $244,30,32,33,353$ \\
\hline $\begin{array}{l}\text { Low } \\
\text { knowledge- } \\
\text { intensive } \\
\text { services }\end{array}$ & Dummy & One, if firm is from NACE 51, 60, 63 \\
\hline $\begin{array}{l}\text { Knowledge- } \\
\text { intensive } \\
\text { services }\end{array}$ & Dummy & $\begin{array}{l}\text { One, if firm is from NACE 61, 62, 64, 65, 66, 67, 72, 73, 74.2, } \\
74.3\end{array}$ \\
\hline
\end{tabular}


Table 4 Coefficients of the bivariate probit model estimation

\begin{tabular}{|c|c|c|c|c|}
\hline & \multicolumn{2}{|c|}{ Germany } & \multicolumn{2}{|c|}{ Portugal } \\
\hline & Domestic & Foreign & Domestic & Foreign \\
\hline \multirow{2}{*}{ Exports status (1998) } & -0.103 & $0.347^{\star \star \star}$ & -0.002 & 0.123 \\
\hline & [0.098] & [0.136] & [0.152] & [0.193] \\
\hline \multirow{2}{*}{ Domestic group dummy } & -0.010 & -0.031 & $0.457^{\star \star \star}$ & 0.254 \\
\hline & {$[0.106]$} & {$[0.136]$} & {$[0.136]$} & {$[0.155]$} \\
\hline \multirow{2}{*}{ Multinational dummy } & 0.102 & 0.076 & 0.033 & $0.526^{\star * *}$ \\
\hline & [0.129] & {$[0.146]$} & {$[0.180]$} & {$[0.185]$} \\
\hline \multirow{2}{*}{ Skills dummy } & $0.311^{* * \star}$ & $0.277^{\star *}$ & $0.358^{\star \star \star}$ & $0.313^{\star \star}$ \\
\hline & [0.091] & {$[0.113]$} & {$[0.137]$} & {$[0.151]$} \\
\hline \multirow{2}{*}{ Engagement R\&D dummy } & $0.468^{\star \star *}$ & $0.2779^{*}$ & $0.327^{\star \star}$ & $0.511^{* * *}$ \\
\hline & {$[0.105]$} & {$[0.144]$} & {$[0.130]$} & {$[0.162]$} \\
\hline \multirow{2}{*}{ Innovation intensity } & 0.251 & $1.921^{z z}$ & $4.341^{\mathrm{zz}}$ & 4.085 \\
\hline & [0.880] & [0.973] & {$[1.742]$} & [2.079] \\
\hline \multirow{2}{*}{ Innovation intensity (square) } & 0.847 & $-1.067^{z z}$ & $-9.698^{z z}$ & -8.546 \\
\hline & [1.412] & [1.404] & [4.365] & {$[5.521]$} \\
\hline \multirow{2}{*}{ Public funding for innovation dummy } & $0.942^{\star * *}$ & $0.557^{* \star *}$ & $0.681^{\star \star *}$ & $0.354^{\star * *}$ \\
\hline & {$[0.089]$} & {$[0.108]$} & [0.122] & {$[0.136]$} \\
\hline \multirow{2}{*}{ Incoming spillovers } & 0.239 & 0.243 & 0.296 & 0.211 \\
\hline & {$[0.149]$} & {$[0.189]$} & [0.194] & {$[0.221]$} \\
\hline \multirow{2}{*}{ Outgoing spillovers } & $1.050^{\star * *}$ & $1.102^{\star \star *}$ & 0.963 & $2.164^{\star \star \star}$ \\
\hline & [0.184] & [0.219] & [0.783] & {$[0.834]$} \\
\hline \multirow{2}{*}{ Medium firm dummy $(50<=$ employees $<250$ ) } & 0.163 & $0.227^{*}$ & $0.260^{*}$ & $0.514^{* * *}$ \\
\hline & {$[0.099]$} & {$[0.129]$} & [0.142] & [0.178] \\
\hline \multirow{2}{*}{ Large firm dummy (employees=> 250) } & $0.501^{\star \star \star}$ & $0.581^{\star * \star}$ & $0.578^{\star \star \star}$ & $0.695^{\star \star \star}$ \\
\hline & {$[0.111]$} & [0.138] & {$[0.177]$} & [0.209] \\
\hline \multirow{2}{*}{ Medium-tech manufacturing firm dummy } & 0.169 & 0.030 & 0.176 & 0.242 \\
\hline & [0.138] & {$[0.174]$} & [0.142] & [0.158] \\
\hline \multirow{2}{*}{ Hi-tech manufacturing firm dummy } & $0.415^{\star *}$ & 0.102 & -0.150 & -0.020 \\
\hline & [0.178] & {$[0.215]$} & [0.272] & {$[0.280]$} \\
\hline \multirow{2}{*}{ Low knowledge-intensive service firm dummy } & $0.535^{\star \star *}$ & 0.182 & $0.387^{*}$ & 0.084 \\
\hline & {$[0.171]$} & [0.234] & {$[0.202]$} & [0.258] \\
\hline \multirow{2}{*}{ Knowledge-intensive service firm dummy } & $0.263^{*}$ & 0.222 & 0.313 & 0.202 \\
\hline & [0.160] & {$[0.202]$} & [0.194] & {$[0.216]$} \\
\hline \multirow[t]{2}{*}{ Eastern Germany dummy } & -0.015 & $-0.382^{\star \star \star}$ & & \\
\hline & [0.091] & [0.118] & & \\
\hline \multirow{2}{*}{ Constant } & $-2.255^{\star \star \star}$ & $-2.978^{\star * \star}$ & $-2.276^{\star \star \star}$ & $-2.933^{\star \star \star}$ \\
\hline & {$[0.186]$} & [0.255] & {$[0.221]$} & [0.291] \\
\hline Observations & \multirow{3}{*}{\multicolumn{2}{|c|}{$\begin{array}{c}1510 \\
-1053.02 \\
435.90\end{array}$}} & \multirow{3}{*}{\multicolumn{2}{|c|}{$\begin{array}{c}774 \\
-549.19 \\
172.40\end{array}$}} \\
\hline LL & & & & \\
\hline$x^{\wedge} 2$ & & & & \\
\hline
\end{tabular}

Standard errors in brackets

* significant at $10 \%$; ** significant at $5 \%$; ${ }^{* *}$ significant at $1 \%$; ${ }^{\mathrm{zz}}$ jointly significant at the $95 \%$ level All dummy variables: $\mathrm{dF} / \mathrm{dx}$ is for discrete change of dummy variable from 0 to 1 


\section{$7 \quad$ References}

Abramovsky, L., E. Kremp, A. López, T. Schmidt, and H. Simpson (2005), Understanding Co-operative R\&D Activity: Evidence from Four European Countries, IFS Working Papers W05/23, London.

Adams, J., and M. Marcu (2004), R\&D Sourcing, Joint Ventures and Innovation: A Multiple Indicators Approach, NBER Working Paper 10474, Cambridge.

Arora, A., and A. Gambardella (1990), Complementarity and External Linkages: the Strategies of the Large Firms in Biotechnology, Journal of Industrial Economics 38, 361-379.

Aschhoff, B. and T. Schmidt (2006), Empirical Evidence on the Success of R\&D Co-operation - Happy together?, ZEW Discussion Paper 06-062, Mannheim.

Bayona, C., T. Gracia-Marco and E. Huerta (2001), Firms' motivation for cooperative R\&D: An empirical analysis of Spanish firms, Research Policy 30 (8), 1289-1307.

Becker, W., and J. Dietz (2004), R\&D Cooperation and Innovation Activities of Firms: Evidence for the German Manufacturing Industry, Research Policy 33, 209-223.

Belderbos, R., M. Carree, B. Diederen, B. Lokskin, and R. Veugelers (2003), The Determinants of R\&D Cooperation: Evidence from Dutch CIS Data 19961998. ZEW Workshop on The Empirical Economics of Innovation and Patenting, Mannheim (Germany), March 14-15.

Belderbos, R., M. Carree, B. Diederen, B. Lokshin and R. Veugelers (2004), Heterogeneity in R\&D Cooperation Strategies, International Journal of Industrial Organization 22 (8-9), 1237-1263. 
Bóia, M.J. (2003), Determinants of Innovation in Portugal: Designing, Implementing and Analyzing Evidence from the Third Community Innovation Survey, Master Thesis in Engineering Policy and Management of Technology, Lisbon.

Bönte, W., and M. Keilbach (2005), Concubinage or Marriage? Informal and Formal Cooperations for Innovation, International Journal of Industrial Organization 23, 279-302.

Bureth, A., R. Levy, J. Penin and S. Wolff (2006), Strategic Reasons for Patenting: Between Exclusion and Coordination Rationales, Revista de Politica Economica, 95(9/10), 19-46.

Busom, I. and A. Fernandez-Ribas (2004), Firm Strategies in R\&D: Cooperation and Participation in R\&D Programs, Universida Autonoma de Barcelona Working Paper No. 04.05, Barcelona.

Caloghirou, Y., S. Ioannides, and N. Vonortas (2003), Research Joint Ventures, Journal of Economic Surveys 17, 541-570.

Capron, H. and M. Cincera (2004), Industry-University S\&T Transfer: What can we Learn From Belgium CIS-2 Data?, CEPR Discussion Paper Series No. 4685, London.

Cassiman, B. and R. Veugelers (2002), R\&D Cooperation and Spillovers: Some Empirical Evidence from Belgium, American Economic Review 44 (3), 1169-1184.

Cohen, W.M. and D.A. Levinthal (1989), Innovation and Learing: The Two Faces of R\&D, Economic Journal 99 (297), 569-596.

Cohen, W.M. and D.A. Levinthal (1990), Absorptive Capacity: A New Perspective on Learning and Innovation, Administrative Science Quarterly 35 (1), 128-152. 
Conceição, P., P. Ávila (2001), A Inovação em Portugal: II Inquérito Comunitário às Actividades de Inovação (in Portuguese), Celta Editora, Oeiras.

Czarnitzki, D., and A. Fier (2003), Publicly Funded R\&D Collaborations and Patent Outcome in Germany, ZEW Discussion Paper 03-24, Mannheim.

D’Aspremont, C. and A. Jacquemin (1988), Cooperative and Noncooperative R\&D in Duopoly with Spillovers, American Economic Review 78 (5), 1133-1137.

Dachs, B., B. Ebersberger and A. Pyka (2004), Why do Firms Co-operate for Innovation? A Comparison of Austrian and Finnish CIS 3 Results, Volkswirtschaftliche Diskussionsreihe der Uni Augsburg No. 255, Augsburg.

De Bondt, R. and R. Veugelers (1991), Strategic Investment with Spillovers, European Journal of Political Economy 7 (7), 345-366.

Dodgson, M. (1994), Technological Collaboration and Innovation, in: Dodgson, M. and R. Rothwell (eds.), The Handbook of Industrial Innovation, Edward Elgar, Cheltenham, 285-292.

Ebling, Günther and Norbert Janz (1999), Export and Innovation Activities in the German Service Sector: Empirical Evidence at the Firm Level, ZEW Discussion Paper No. 99-53, Mannheim.

Eickelpasch, A., and M. Fritsch (2005), Contests for Cooperation - A new Approach in German Innovation Policy, Research Policy 34, 1269-1282. Eurostat (2004), Innovation in Europe Results for the EU, Iceland and Norway Data 1998-2000, Office For Official Publication of the European Communities, Luxemburg.

Eurostat (2007a), More than 40\% of EU27 enterprises are active in innovation, News Release 27/2007, February 22 ${ }^{\text {nd }}$ 2007, Luxemburg. 
Eurostat (2007b), Community Innovation Statistics - Is Europe growing more innovative?, Statistics in Focus 61/2007, Luxemburg.

Fontana, R., A. Geuna and M. Matt (2005), Factors Affecting University-Industry $R \& D$ Collaboration: The Importance of Screening and Signalling, Document de travail No. 2005-07, Strasburg.

Fritsch, M. and R. Lukas (2001), Who Cooperates on R\&D?, Research Policy 30 (2), 297-312.

Glaister, K.W. and P.J. Buckley (1996) Strategic Motives for International Alliance Formation, Journal of Management Studies 33 (3), 301-332.

Gomes-Casseres, B., J. Hagedoorn and A. Jaffe (2006), Do Alliances Promote Knowledge Flows?, Journal of Financial Economics 80, 5-33.

Hagedoorn, J. (1993), Understanding the Rationale of Strategic Technology Partnering: Interorganizational Modes of Cooperation and Sectoral Differences, Strategic Management Journal 14 (5), 371-385.

Hagedoorn, J. (2002), Inter-firm R\&D Partnership: An Overview of Major Trends and Patterns since 1960, Research Policy 31 (4), 477-492.

Hagedoorn, J., N.L. Albert, and N.S. Vonortas (2000), Research Partnerships. Research Policy 29, 567-586.

Heckman, J.J. (1976), The Common Structure of Statistical Models of Truncation, Sample Selection and Limited Dependent Variables and a Simple Estimator for Such Models, Annals of Economic and Social Measurement 5, 475-492.

Heckman, J.J. (1979), Sample Selection Bias as a Specification Error, Econometrica 47, 153-161. 
Janz, N., G. Ebling, S. Gottschalk and H. Niggemann (2001), The Mannheim Innovation Panels (MIP and MIP-S) of the Centre for European Economic Research (ZEW), Journal of Applied Social Science Studies 121 (1), 123129.

Kaiser, U. (2002) An Empirical Test of Models Explaining Research Expenditures and Research Cooperation: Evidence for the German Service Sector, International Journal of Industrial Organization 20 (6), 747-774.

Kamien, M.I., E. Muller and I. Zang (1992), Research Joint Ventures and R\&D Cartels, American Economic Review 82 (5), 1293-1306.

Kingsley, G., and E. Malecki (2004), Networking for Competitiveness, Small Business Economics 23, 71-84.

Li, J. and J. Zhong (2003), Explaining the Growth of International R\&D Alliances in China, Managerial and Decision Economics 24, 101-115.

Link, A.N. and L.L. Bauer (1987), An Economic Analysis of Co-operative Research, Technovation 6, 247-260.

Luo, Y. (2004), Coopetition in International Business, Copenhagen Business School Press, Copenhagen.

Dodgson, M. (1994), Technological Collaboration and Innovation, in: Dodgson, M. and R. Rothwell (eds.), The Handbook of Industrial Innovation, Edward Elgar, Cheltenham, 285-292.

Miotti, L. and F. Sachwald (2003), Cooperative R\&D: Why and with Whom? An Integrated Framework Analysis, Research Policy 32 (8), 1481-1499.

Mowery, D. (1983), The relationship between Intrafirm and Contractual Forms of Industrial Research in American Manufacturing, Explorations in Economic History 20, 351-374. 
Mowery, D., J. Oxley and B. Silverman (1998), Technological Overlap and Interfirm Cooperation: Implications for the Resource-based View of the Firm, Research Policy 27, 507-523.

Narula, R. and J. Hagedoorn (1999), Innovation Through Strategic Alliances: Moving Towards International Partnerships and Contractual Agreements, Technovation 19, 283-294.

Negassi, S. (2004), R\&D cooperation and innovation a microeconometric study on French firms, Research Policy 33 (3), 365-384.

Nelson, R. (1990), U.S. Technological Leadership: Where Did it Come from and where did it go?, Research Policy 19, 193-214.

Nijssen, E., R. Van Reekum and H. Hulshoff (2001), Gatheting and Using Information for the Selection of Technology Partners, Technological Forecasting and Social Change 67, 221-237.

OECD (1986), Technological Cooperation Agreements between Firms: Some Initial Data and Analysis, Paris.

OECD (1992), Proposed Guidelines for Collecting and Interpreting Technology Innovation Data - Oslo Manual, Paris.

Palmberg, C. and M. Pajarinen (2005), Determinants of Internationalisation through Strategic Alliances - Insights Based on New Data on Large Finnish Firms, The Research Institute of the Finnish Economy Discussion Papers 966, Helsinki.

Penin, J. (2005), Patents versus ex post rewards: A new look, Research Policy 34, 641-656.

Rammer, C., B. Peters, T. Schmidt, B. Aschhoff, T. Doherr and H. Niggemann (2005a), Innovationen in Deutschland - Ergebnisse der Innovationserhebung 2003 in der deutschen Wirtschaft, ZEW Wirtschaftsanalysen Band 78, Nomos Verlagsgesellschaft, Baden-Baden. 
Rammer, C., B. Peters, T. Schmidt and T. Doherr (2005b), Innovation in Germany - Results of the German Innovation Survey 2004, ZEW Mannheim, Mannheim.

Röller, L.-H., M.M. Tombak and R. Siebert (1997), Why firms form Research Joint Ventures: theory and evidence, CEPR Discussion Paper Series No. 1654, London.

Rosenfeld, S. (1996), Does Cooperation Enhance Competitiveness? Assessing the Impacts of Inter-firm Collaboration, Research Policy 25, 247-263.

Sakakibara, M. (1997), Heterogeniety of Firm Capabilities and Cooperative Research and Development: An Empirical Examination of Motives, Strategic Management Journal 18 (6), 143-165.

Schmidt, T. (2005), Absorptive Capacity - One Size Fits All? A Firm-level Analysis of Absorptive Capacity for Different Kinds of Knowledge, ZEW Discussion Paper No. 05-72, Mannheim.

Schmidt, T. (2006), An Empirical Analysis of the Effects of Patents and Secrecy on Knowledge Spillovers, ZEW Discusssion Paper No. 06-048, Mannheim.

Sofka, W. and T. Schmidt (2004), I Like The Way You Move: An Empirical Investigation into the Mechanisms Behind First Mover and Follower Strategies, ZEW Discussion Paper No. 04-87, Mannheim.

Tether, B. (2002), Who Co-operates for Innovation, and Why: An Empirical Analysis, Research Policy 31 (6), 947-967.

Tsang, E.W.K. (2000), Transaction Cost and Resource-based Explanations of Joint Ventures: A Comparison and Synthesis, Organizational Studies 21 (1), 215-242. 
Von Zedtwitz M. and O. Gassmann (2002), Market versus Technology Drive in R\&D Internationalization: Four Different Patterns of Managing Research and Development, Research Policy 31, 569-588. 